w dziesiątą rocznicę jego śmierci oddaje mu glęboki hołd i podziękowanie za wzór biblisty egzegezy, naukowca rzetelnego, wytrwalego w poszukiwaniu prawdy, czlowieka, któremu nic co biblijnego nie bylo obce.

Łódź - Lublin

KS. LECH STACHOWIAK

Zdzislaw 3. Kapera

\title{
O PELNIEJSZĄ OCENĘ DOROBKU ONOMASTYCZNEGO KS. ALEKSEGO KLAWKA
}

Jest rzeczą zastanawiającą, iż nie znamy genezy zainteresowan onomastycznych ks. prof. A. Klawka. Nie pisze nawet o tym nawet jeden $z$ najbliższych jego przyjaciół, prof. A. Taszycki. Oczywiście bazą dla tych dociekań stały się z pewnością „filologiczne upodobania" wskazane przez. prof. W. Taszyckiego w artykule Ks. Aleksy Klawek jako onomasta ${ }^{1}$. Ale nie tylko, Bo przecież - jak to słusznie zauważa Ks. F. Gryglewicz - artykułem (z roku 1925) o imieniu Jezus - ks. Klawek „wszedł we własny, filologiczny nurt biblijnych badań". I „te wlasne, filologiczne badania biblijnych problemów poglębial on ciągle" 2. Po blisko 25 latach wracal ks. A. Klawek do problematyki imienia Jahwe, czy imienia Maryi, a także - czego nie zauważono, przygotowywal on do druku (dotąd nie opublikowany) tekst obszernego studium "Imię Jezus w świetle filologii biblijnej" Jak stwierdziłem, krótki, niesłychanie zwarty referat o imieniu Jezus, który stoi u początku publikacji onomastycznych Ks. A. Klawka, zamieszczony w "Sprawozdaniach Towarzystwa Naukowego we Lwowie za rok 1925", jest niczym innym jak streszczeniem cytowanej obszernej pracy o ważkim ciężarze gatunkowym ${ }^{4}$. Zreferowanie je na posiedzeniu Wydziału Filologicznego Towarzystwa w dn. 17 listopada $1924 \mathrm{r}$. związane było $z$ uzyskaniem zaszczytnego członkowstwa Lwowskiego Towarzystwa Naukowego, tak jak krótkie studium o imionach Jahwe i Elohim przyniosło Ks. A. Klawkowi członkowstwo Komisji Orientalistycznej Polskiej Akademii Umiejętności w $T$.

1 Por. „Ruch Biblijny i Liturgiczny” 23, 1970, ss. 291-293 i przedruk w ,Onomastica" 17, 1972, ss. 304-306.

2 F. Gryglewicz, Badania ks. prof. A. Klawka nad Nowym Testamentem, RBL 23, 1970, s. 278 n.

3 „Sprawozdania Towarzystwa Naukowego we Lwowie” 5, 1925, ss. 3-4.

- Sygnalizowałem ją po raz pierwszy pod nr 310 w Bibliografii prac księdza Aleksego Klawka (1890-1969), profesora U.J.K. $i$ U.J., RBL 23 , 1970 , s. 333. 
$1932^{5}$. Już ta pierwsza praca o imieniu Jezus, wzbudzila żywe zainteresowanie. Kronikarz Towarzystwa podaje, że w dysikusji glos zabrali profesorowie W. Bruchnalski, R. Gansiniec i St. Witkowski. Jak się wydaje genezy pracy o imieniu Jezus należy szukać nie w polowie lat 20-tych, gdy byla referowana, lecz $w$ przelomie lat 1918-1919. 13 czerwca 1918 r. ks dr Klawek wyglosił w ramach Wydzialu Teologicznego Poznańskiego Towarzystwa Przyjaciól Nauk swój pierwszy referat pt. "Gloria in Excelsis Deo, historyczność i egzegeza hymnu anielskiego w świetle najnowszych badañ", ale już drugi referat, z dnia 16. X. 1919 r. dotyczy właśnie imienia Jezus ${ }^{6}$. Czym należy tłumaczyć to wyraźne odejście od nowotestamentalnej problematyki, sensu stricto egzegetycznej i apologetycznej, gdyz w tym nurcie należy ustawić pierwsze publikacje ks. A. Klawka - do problematyki ściśle filologicznej? Co skłoniło ówczesnego wikarego z Rydzyny kolo Leszna w Wielkopolsce, a od wiosny 1919 rokiu wylkiadowcy w gnieźnienskim Seminarium Duchownym, do podjęcia tak szczególowych badań? Czy krótką, dwutygodniową wizytę (6-19 października 1918 r.) w Seminarium Orientalistycznym Uniwersytetu Humboldta $w$ Berlinie oraz $w$ Bibliotheca Regia Berolinensi - celem zebrania materiałów do pracy naukowej nie należałoby wiązać właśnie ze szczególowymi studiami filologicznymi nad imieniem Jezus? ? A może podjęcie studiów $z$ zakresu onomastyki biblijnej związane bylo $z$ przypadającymi na rok 1917 naukowymi wizytami we Wrocławiu i Monachium, gdzie wspólpracowal ze znakomitymi biblistami Janem Niklem i Józefem Sichenbergerem? Dziś nie patrafimy już chyba odpowiedzieć na postawione powyżej pytania. Należy jednak skorygować, iż ks. A. Klawek swym zainteresowaniom onomastycznym dà wyraz po raz pierwszy juź w roku 1919, w wieku lat 29 , jeszcze w okresie pobytu w Wielkopolsce, przed nawiązaniem kontaktów ze środowiskiem lwowskim. Jego poczynania onomastyczne należy zlokalizować w jednym ciągu z pracami filologów niemieckich, którzy w ostatniej ćwierci XIX w. ożywili studium imion biblijnych: prace E. Nestlego, 1875, M. Grunwalda, 1895, P. Kerbera, 1897, F. Ulmera, 1901 oraz uczonych angielskich np. G. B. Graya, 1896 i innych, a przed epokową pracą M. Notha, Die israelitischen Personennamen im Rahmen der gemeinsemitischen Namengebung, Stuttgart 1928. Moźna jedynie ubolewać, iż dysertacja ks. A. Klawka

5 Imiona hebrajskie Boga Jahweh $i$ Elohim, ,Sprawozdania P.A.U. 37, 1932, nr 4, ss. 4-7 oraz wersja francuska: Les noms hébraiques "Jahweh" et "Elohim", Bulletin International de l'Académie Polonaise des Sciences et Lettres" 1932, nr 4-6, ss. 88-92.

- Por. N. C., Wydzial Teologiczny przy T.P.N. $w$ Poznaniu, „Przeglad Teologiczny" 2, 1921, s. 188.

7 Wizyte w Berlinie sygnalizuje M. Wolniewicz, Studium Pisma Swiętego w Arcybiskupim Seminarium Duchowinym w Poznaniu w latach 1835-1939, Poznań 1969 (= Sprawy Biblijne 22); ss. 58 n. 
nie zostala opublikowana w trudnych latach 20-tych. Moim zdaniem $z$ pewnością weszłaby na stałe do dorobku światowej onomastyki biblijnej. Tymczasem nawet to publikowane jej streszczenie nie weszlo w krwiobieg choćby tylko polskiej biblistyki. Skoro ks. A. Klawelk zdecydowal się na kilka lat przed śmiercią opublikować to - zdar waloby się zestarzałe już studium, to dlatego, iż jego zdaniem, nie ukazala się dotąd paralelna praca o podobnym ciężarze filologicznym. Uzasadnienie, które podał w rękopisie z początku lat dwudziestych „sądzę, że temat wcale nie jest aktualny, gdyż - dziwna to rzecz - imieniu najdroższemu dla każdego chrześcijanina nie poświęcono dotąd żadnego specjalnego badania" (rkp. cyt., s. 1) zachowalo nadal swą wagę. Przykladowo jedna $z$ nowszych prac J. Weber, Der Name über alle Namen. Die Botschaft biblischer Jesusnomen (Berlin 1970), ujmuje niemal wyłącznie teologiczne aspekty tytulow Jezusa: Jezus, Chrystus, Pan, aż po Cieślę. Najnowsze encyklopedi biblijne nie notuja w partiach biblingraficznych właściwie żadnego studium o samym imieniu. Najobszerniejszą dokumentację filologicz ną zawiera artykul W. Foerstera ${ }^{8}$.

Opracowana przez ks. A. Klawka monografia imienia Jezus ma objętość ok. 6 ark. autorskich. Składa się z trzech rozdziałów: $R$. I. Imię Jehošua Jezus w języku hebraj̆skim. Wstęp (rkps ss 1-2), §1 W epoce' Starego Testamentu (ss. $3-21$ ), § 2. W epoce. Nowego Testamentu (ss. 22-29), § 3. W epoce Talmudu i zzasach późniejszych (ss. 30-35). Rozdzial II: Imię Jezus $w$ języku greckim. § 1 . W Bibli (ss. 36-44) § 2. Poza Biblią (ss. 44-51). Rozdzial III. Imię Jezusv $w$ innych językach (ss. 52-55). Ubolewać należy, że praca nad ręko. pisem ograniczyła się do adaptacji celem przepisania na maszynite oraz naniesieniem uwag o publikacjach, które cytował non vidi, a do których mógł ustosunkować się po latach znalazłszy je w krakowskich księgozbiorach lub wypożyczywszy za pośrednictwem wypożyczalni międzybibliotecznej krakowskiej biblioteki PAN. Do proble= matyki imienia Jezus ks. A. Klawek już po wojnie, nie wrócił (luł raczej nie zdążył już nic opublikować) poza luźną uwagą w streszczeniu wykładu o etymologii ważniejszych imion biblijnych, $z \quad \mathrm{E}$ 1964\%. Zająi się natomiast i powracal do niego wielokrotnie imieniem Maryja. Opublikował „Uwagi filologiczne o imieniu Marja w r. 1926 a następnie rozważał trzykrotnie jego pochodżenie i et mologię w artykułach z r. 1947, 1949 i $1951^{10}$. Odrzuciwszy domysi

3 Por. Theologisches Wörterbuch zum N. T., t. III, ss. $284-294$.

9 Etymologia ważniejszych imion biblijnych, "Sprawozdania Oddzialı PAN w Krakowie", styczeń-czerwiec 1964, ss. 101-102.

10 Byly to kolejno artykuły: Uwagi filologiczne o imieniu, Maryja Prz. Teol. 7, 1926, ss. 434 436; Etymologia imienia Maris, "Spraw. PAU" 48,1947 , s. 402 ; Etymologia imienia Maria, „Polonia Sacra" 1, 1948, ss. 176-184: Imie Maria. Et nomen virginis Maria (Euk 1, 27), RBL 4, 1951, ss. $56-58$. 
alegoryczne sięgające doby Ojców Kościola, krytykuje argumenty filologiczne swych poprzedników, podkreślając z naciskiem, że problem jest tak trudny, iż nawet $M$. Noth zrezygnowal z podania etymologii imienia Maryja ${ }^{11}$. Chciałbym dodać, że wycofal się z możliwości podania jakiegokolwiek rozwiązania również znakomity G. Stählin ${ }^{12}$. Ks. A. Klawek odrzucił sugestię H. Grimmego, że imię to jak większość imion biblijnych jest imieniem teoforycznym, oraz przypuszczenie F. Zorella o jego egipskim pochodzeniu. Wysunąi własną sugestię: końcówka -am wskazuje na zdrobniałość. W pierwszej natomiast zglosce mar- tkwi, jego zdaniem, prawdopodobnie rdzeń rawah - pić, poić obficie, przy czym rawah należy brać przenośnie: pić radość, napawać radością. Glosa kananejska w liście 147 z Tel Amarna potwierdza, że rawah (jako causativum) używane bylo w sensie ..napawać radościa". A więc imię "marjam" oznacza dziecko (dziewczynkę), której narodzenie napawa rodziców radością" 13. Warto dodać, że dopiero niedawno, ktoś inny odważył się pழ̣stawić odrębną propozycję etymologii imienia Maryja. W. von Soden sugeruje w oparciu o teksty południowo-kananejskie, z rejonu Midian, że chodzi tu o podarek, dar, prezent (dosł. Geschenk) - mirjäm, a więc Maria byloby, cytuje, ,(Gottes) - Geschenk" 14 .

Nie będę tutaj analizował ani zajmowal się oceną kolejnej większej publikacji onomastycznej ks. A. Klawka, tj. studium Onomastyka biblijna ${ }^{15}$. „Jest to zwięzła i dokładna historia onomastyki biblijnej zestawiająca wszelką napisaną na ten temat literaturę, zarówno biblijna jak i pozabiblijna", jak to trafnie ocenił ks. prof. S. Grzybek w recenzji na łamach „Ruchu Biblijnego i Liturg.” w r. 1962 (s. 256). $Z$ całą pewnością, cytuję tu inny fragment tej recenzji, „pokolenie miodych biblistów, jak również i studiującej biblistykę młodzieży może czerpać z tej pracy cenne wiadomości natury merytorycznej i metodologicznej". Ze swej strony dodam, iż pobieżny rzut oka na opracowania encyklopedyczne wskazuje, iż nawet literatura zachodnia nie dysponuje tak zwartym i ścisłym wprowadzeniem do onomasiyki biblijnej.

Jest rzeczą charakterystyczną, że z wrodzoną sobie skromnością ks. A. Klawek pomija, w cytowanym studium Onomastyka biblijna swój własny wkład do dziejów polskiej onomastyki biblijnej. Wzmiankuje jedynie dwa swe artykuły jeden o imionach Jahwe i Elohim oraz drugi o imieniu miasta Jerozolima ${ }^{16}$. Wskazuje natomiast na

II M. Noth, Die israelitischen Personennamen, Stuttgart 1928, s. 250.

12 Por. Die Religion in Geschichte und Gegenwart, Tübingen 1956, wyd. 3 , t. 4 , s. 747 .

Is "Polonia Sacra" 1, 1948, ss. 183 n.

14 Por. W. von Soden, Mirjäm - Maria ,(Gottes-) Geschenk", Ugarit-Forschungen 2, 1970, pp. 269-272.

15 ,Onomastica" 7,1961 , ss. $403-416$.

16 De pronuntiatione vocis Jerusalem, "Collectanea Theologica" 13, 1932 , ss. $384-387$. 
wklad ks. W. Szczepańskiego do toponomastyki krajów biblijnych. 'Trzeja bowiem ṕamiętać, że ks. Szczepanski zasłużył się dwoma znakomitymi na owczesne czasy pracami: Geographia Historicae Palestinae Antiquae (1. wydanie Rzym 1912, a więc zaledwie kilka lat przed pierwszymi studiami onomastycznymi podjçtymi przez ks. Klawka) oraz Mieszkańcy Palestyny Pierwotnej, Kraków 1920. W tej ostatnie wyjaśnial nazwy najdawniejszych plemion palestyniskich. Może do tych dwu prac należałoby jeszcze dodać Palestynę za czasów Chrystusa Pana, Kraków 1922, również zawierającej pewien material toponomastyczny (np. opisane są dzieje nazwy Jerozolima). Trudno ustalić, czy ktoś poza ks. Szczepańskim i ks. Klawkiem próbował swych sił w zakresie onomastyki biblijnej w latach 20 -tych. Praca doktorska ks. Wronki o imieniu Jahwe dotyczyła wlaściwie (sądząc ze streszczenia referatu wygloszonego w Poznańskim Towarzystwie Przyjaciól Nauk) wyjścia z użycia tego imienia w tekstach biblijnych i zastapienia go przez Adonaj 17. W Polskicj bibliografii biblijnej od 1900-1930 r. brak jakiejkolwiek wzmianki o studiach onomastycznych, zaś bibliografia za lata 1931-1965 dla okresu przedwojennego notuje wiaściwie tylko jedną pracę $z$ tego zakresu: studium T. Radkowskiego Hebrajskie imiona boże. Spostrzeżenia stare $i$ nowe; w którym rozważył imiona Jahwe, Elohim, Eloh, El, Adonaj, Eljon, Szadai 18 .

IV okresie powojennym w Polsce następuje ożywienie badan onomastycznych. Jest to zasługą prof. W. Taszyckiego, kierownika komisji ustalającej urzẹdowe nazwy miejscowości obiektów fizograficznych $\mathrm{w}$ naszym kraju. $\mathrm{Na}$ marginesie prowadzonyeh badan powstają prace $z$ zakresu onomastyki i toponomastyki neohebrajskiej pióra M. Altbauera. Wyłączam je tutaj z dyskusji, gdyż nie dotyczá one onomastyki biblijnej sensu stricto. Te dyscyplinę reprezentowal nadal jedynie ks. A. Klawek. Trudno bowiem uznać za wkład do tej dyscypliny popularnonaukowe artykuliki $\mathrm{H}$. Koniecznego i $\mathrm{S}$. Kowalskiego 0 imieniu Jezus ${ }^{19}$. Jedyny naukowy przyczynek do problematyki onomastycznej doby lat 60 -tych, to apendyks ks. S. Eacha, pt. Imię Boże Jahwe, zamieszczony w komentarzu do Księgi Wyjścia 20. Choć ter obszerny paragraf ma swoją bazę filologiczną, jest on jednak w swym charakterze raczej przyczynkiem do teologii imienia bożego niż studium onomastycznym.

17 Por. A. Wronka, Imię Jahwaeh w hebrajskich księgach Starego Testamentu, „Sprawozdania PTPN" 1, 1927, s. 45.

18 Por. Miscellanea Theologica. Pracä zbiorowa profesorów Seminarium Metropolitalnego w Warszawie, Warszawa 1936, ss. 225-238.

" 39 Por. H. Konieczny, Imie Jezus, "Pielgrzym Polski" 1963, s $46-47$; S. K ow a is ki, Imię Jezus, "Siouso Powszechne" 10, 1956, nr 2, s. 3 ,

20 Ksiega Wyjścia. Wstęp-przeklad $z$ oryginatu-komentarz, oprac. S. E.ach, Poznań 1954 (= Pismo Swięte Starego Testamentu I:2), ss. 303-312. 
$Z$ powyższego przeglądu niezbicie wynika, że ks. A. Klawek był, i co jest rzeczą zaskakującą, pozostał jedynym polskim biblistą o zacięciu onomastycznym. Stąd słusznie jego dzialalność naukową na tym polu ocenil prof. W. Taszycki $w$ dwukrotnie publikowanym artykule Ks. A. Kalawek jako onomasta ${ }^{21}$. Pisal on, że ks. Klowek, ,rozszerzyl zasięg polskich badan onomastycznych o dziedzine dotąd nie reprezentowaną. Wzbogacil je publikacjami, których przedmiotem są wybrane zagadnienia onomastyki Bliskiego Wschodu, glównie semickiej". W złożonej rzeczywistości swego powojennego życia „przystąpil w szerokim zakresie do badań onomastycznyeh" dając "non multa" a przeciez "multum". W historii tej dyscypliny zająl "osobne, trwałe miejsce".

Oceną dorobku onomastycznego ks. Klawka marginainie zająl się także J. Chmiel starając się w art. Mentalność biblisty zwrócić uwagę na specyfikę jego myślenia badawczego. Przyjmując porównanie, przeprowadzone przez Prof. Pigonia, metod pracy badawczej do techniki miniaturowej lub portretowej, ks. Chmiel niezwykle trafnie stwierdza, ze ks. A. Klawek ,był wybornym miniaturzystą". "Niektóre jego szkice filologiczne, $z$ w $\mathbf{l}$ a s z cza on om as ty c z ne (podkreślenie moje), to skonczone miniatury, zamknięte precyzyjnie w swoich owalach. Niemniej w tych miniaturach, w tych analizach mieści się już synteza”, księdza Klawka, bowiem „poprzez małe formy dochodził do syntetycznych ogarnien" 22. Chciałbym tu jeszcze dodać od siebie, że zachowane rękopiśmienne notatki do niektórych wykładów w Komisjach Orientalistycznej i Językoznawczej Oddziału Krakowskiego PAN, wskazują na głębię przemyśleń i ustaleń, "których z braku czasu ks. Klawek nie zdolał przelać na papier. Nie zapominajmy, że najlepsze miniatury onomastyczne pochodzą z lat 1962-65, w trakcie których, ks. Klawek tak żywo wlączył się w soborowe dyskusje biblijne i teologiczne. Czytając te kilkustronicowe streszczenia odnosi się wrażenie, że cały szereg zwięzłych stwierdzeń zawartych $w$ nich zasługują na rozwinięcie $w$ postaci oddzielnych artykułów. Przykładowo wymienię abstrakt referatu dotyczącego „etymologii imion biblijnych". $\mathrm{Z}_{a}$ przykład jak należałoby te dyspozycje rozwinąć może posłużyć obszerny artykuł ks. A. Klawka dotyczący imion Szymona i Piotra 23.

Nazwisko ks. Klawka w dziejach polskiej onomastyki biblijnej znalazło się już na stałe. Większość polskich uczonych piszących - nim zauważa ten fakt. Szkoda jedynie, że S. Urbańczyk, pisząc aktualnie o dziejach powojennej onomastyki krakowskiej, wzmiankuje zaledwie jedną pracę ks. A. Klawka z 1964 r. nie dostrzegając

1. Por. note 1 .

22 J. Ch miel, Mentalność biblisty, RBL 23,1970, ss. 301.

2s Dwa imiona biblijne: Szymon i Piotr, w: Symbolae Phüologicae in honprem Vitoldi Taszycki, Wrockaw 1968 (= Prace Komisji/Językoznawczej Oddz. PAN w Krakowie nr 17), ss. 155-161. 
w zupelności wyjątkowej tej postaci pośród onomastyków krakowskich oraz jego własnego wkładu w dzieje polskiej onomastyki ${ }^{24}$.

Dlatego z całym przekonaniem o zasiugach ks. A. Klawka dla onomastyki biblijnej śmiem postulować konieczność przedruku prac onomastyeznych ks. Klawka i to nie tylko w języku polskim. Może w ramach dzieł wszystkich, a w każdym razie obok antologii jego tłumaczeń biblijnych ${ }^{25}$. Najwlaściwszym jednak uważałbym wydanie prac onomastycznych w języku angielskim. W ten sposób znakomity, choć objętościowo niewielki dorobek znakomitego językoznawcy zostałby po raz pierwszy udostępniony i skonfrontowany $z$ osiągnięciami czołowych onomastyków biblijnych. Publikacja taka byłaby nie tylko dobrym wprowadzeniem dla każdego biblisty $w$ rzadko uprawianą dyscyplinę, lecz także holdem oddanym zapoznanemu dorobkowi najwybitniejszego polskiego filologa biblijnego bieżące ‘o stulecia.

Kraków ZDZISEAW J. KAPERA

24 S. Urbańczyk, L'onomastique d'après-guerre à Cracovie, „Onoma" 22, 1978 , s. 753 .

${ }^{25} \mathrm{Z}$ inicjatywa przedruku rozproszonych przekładów fragmentów Biblii wystąpil doc. A. Zaborski na posiedzeniu P.T.T. w dziesiąta roczniç 'śmierci ks. prof. A. Klawka w dn. 22. XI. 1979 r.

Stanisław Rospond

\section{ONOMASTICA SACRA W NOWYM TESTAMENCIE}

\section{JEROZOLIMA - JERUZALEM}

O Jeruzalem, Jeruzalem, które zabijasz prorokbw...

(Mt 23, 37: Ek 13, 34)

Onomastyka wspólczesna rozwija się wszechstronnie w obrębie językoznawstwa jako nauka o nazwach własnych i dyscyplina pomostowa; ' lącząc się z archeologią, prehistorią, geografią, topografią, historią osadnictwa, a nawet $\mathrm{z}$ geologią itp. Coraz częściej pojawiają się prace, zwłaszcza w USA, dotyczące tzw. onomastyki literackiej, czyli stylizacji nazewniczej u autorów, którzy posługują się nieraz nazwami wlasnymi znaczącymi (noms - parlants). 